\title{
Avoiding ICD lead revision in a patient with chronically low R-wave amplitudes
}

\author{
Matthias Ernst', László Sághy', Stefan H. Hohnloser², Máté Vámos ${ }^{1,2}$ \\ ${ }^{1}$ University of Szeged, $2^{\text {nd }}$ Department of Medicine and Cardiology Center, Szeged, Hungary \\ ${ }^{2}$ University Hospital Frankfurt - Goethe University, Dep. of Cardiology, Frankfurt am Main, Germany
}

Address for correspondence:

Máté Vámos, MD, PhD, $2^{\text {nd }}$ Department of Medicine and Cardiology Center,

Electrophysiology Division, University of Szeged, Semmelweis u. 8., 6725 Szeged, Hungary

vamos.mate@gmail.com

A patient with non-ischemic cardiomyopathy and a 10-year-old primary prophylactic implantable cardioverter-defibrillator system (ICD) was admitted after experiencing two ICD-shocks. The interrogation of the device revealed chronically low R-wave amplitudes leading to intermittent T-wave oversensing and inappropriate shock delivery. During box exchange, we could avoid lead revision by intraoperative testing and subsequent reprogramming of the sensing vector from true to integrated bipolar configuration in the new generator. This programming feature is currently available only in certain ICD models.

\section{Keywords: ICD, implantable cardioverter defibrillator, T-wave oversensing, sensing vector, true bipolar, integrated bipolar, extended bipolar}

A nem iszkémiás cardiomyopathiában szenvedő, 10 éves, primer profilaktikus indikációval beültetett kardioverter defibrillátor rendszerrel (ICD) elő beteg, két ICD-sokk leadását követően került felvételre. A készülék lekérdezése során, krónikusan alacsony R-hullám-amplitúdók igazolódtak, amelyek intermittáló T-hullám-túlérzékeléshez, majd indokolatlan sokkleadásokhoz vezetettek. A mütét kezdetén az érzékelési vektor tesztelését végeztük el először, amelynek során a valódi bipolárisról integrált bipoláris érzékelésre váltással, és az új telepben történő beállítással, az elektróda revíziója elkerülhetővé vált. Ez a programozási lehetőség jelenleg csak bizonyos ICD-modellekben érhető el.

Kulcsszavak: ICD, beültethető kardioverter defibrillátor, T-hullám túlérzékelés, érzékelési vektor, bipoláris érzékelés, integrált bipoláris, kiterjesztett bipoláris

\section{Introduction}

Implantable cardioverter defibrillators (ICDs) require good quality intracardiac signals for appropriate arrhythmia detection. Low R-wave amplitudes during follow-up of patients with ICDs may lead to delayed detection of ventricular fibrillation (VF) (1), but also to T-wave oversensing with inappropriate ICD shocks (2). Troubleshooting of such cases can be challenging and often require surgical lead revision as the only solution $(2,3)$.

\section{Case Report}

A 48-year-old male patient with a history of nonischemic cardiomyopathy received a primary prophy- lactic VVI-ICD in 2010 (Device: Medtronic Entrust Escudo D144VRC, Lead: Medtronic 6935 Sprint Quattro S, Medtronic Inc., Minneapolis, MN, USA) and a left ventricular assist device in 2011 (Figure 1). He was admitted to the hospital in 2018 after experiencing two ICD shocks. Interrogation of the device revealed 405 non-sustained ventricular tachycardia (nsVT) and 5 sustained ventricular fibrillation (VF) episodes occurring in the last three months - two of those were shocked by the ICD. Further analysis of the shocked VF episodes revealed intermittent T-wave oversensing due to chronically low R-wave amplitude as the trigger of inappropriate shock delivery (Figure 2). R-wave sensing decreased gradually from $13.4 \mathrm{mV}$ to an average of 3-4 $\mathrm{mV}$ in the last two years (last measurement: $3.4 \mathrm{mV}$ ) without any relevant change of other lead parameters.

A kézirat 2019. 12. 10-én érkezett a szerkesztőségbe, 2020. január 6-án került elfogadásra. 


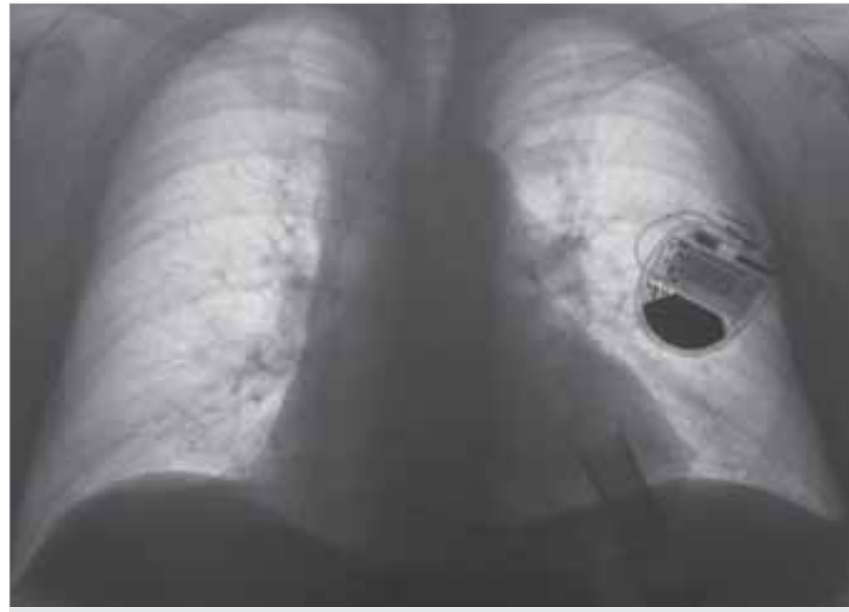

FIGURE 1. Patient's chest X-ray showing the position of the VVI-ICD system and left ventricular assist device in AP view
The patient was scheduled for box replacement (current battery voltage=2.64 V, ERI=2.61 V) and a potential lead revision. Intraoperatively we attempted to maximize the R-wave amplitude and prevent lead revision by testing both true bipolar (tip to ring) and integrated bipolar (tip to coil) sensing vectors. This assessment revealed that tip to coil sensing resulted $\mathrm{R}$-wave amplitudes $>5.0 \mathrm{mV}$ compared to tip to ring sensing (2.1-4.8 $\mathrm{mV}$ ). Since some of the newer generation ICDs have the option to change the sensing vector, we decided to implant such a device (Medtronic Evera S VR, DVBC3D1), programming the sensing vector to integrated bipolar, without need of further lead revision.

The patient was asymptomatic during the next 12 months. Consistent with clinical findings, interrogation of the device revealed excellent sensing values (last measured R-wave amplitude: $9.8 \mathrm{mV}$ ) at regular follow-ups.
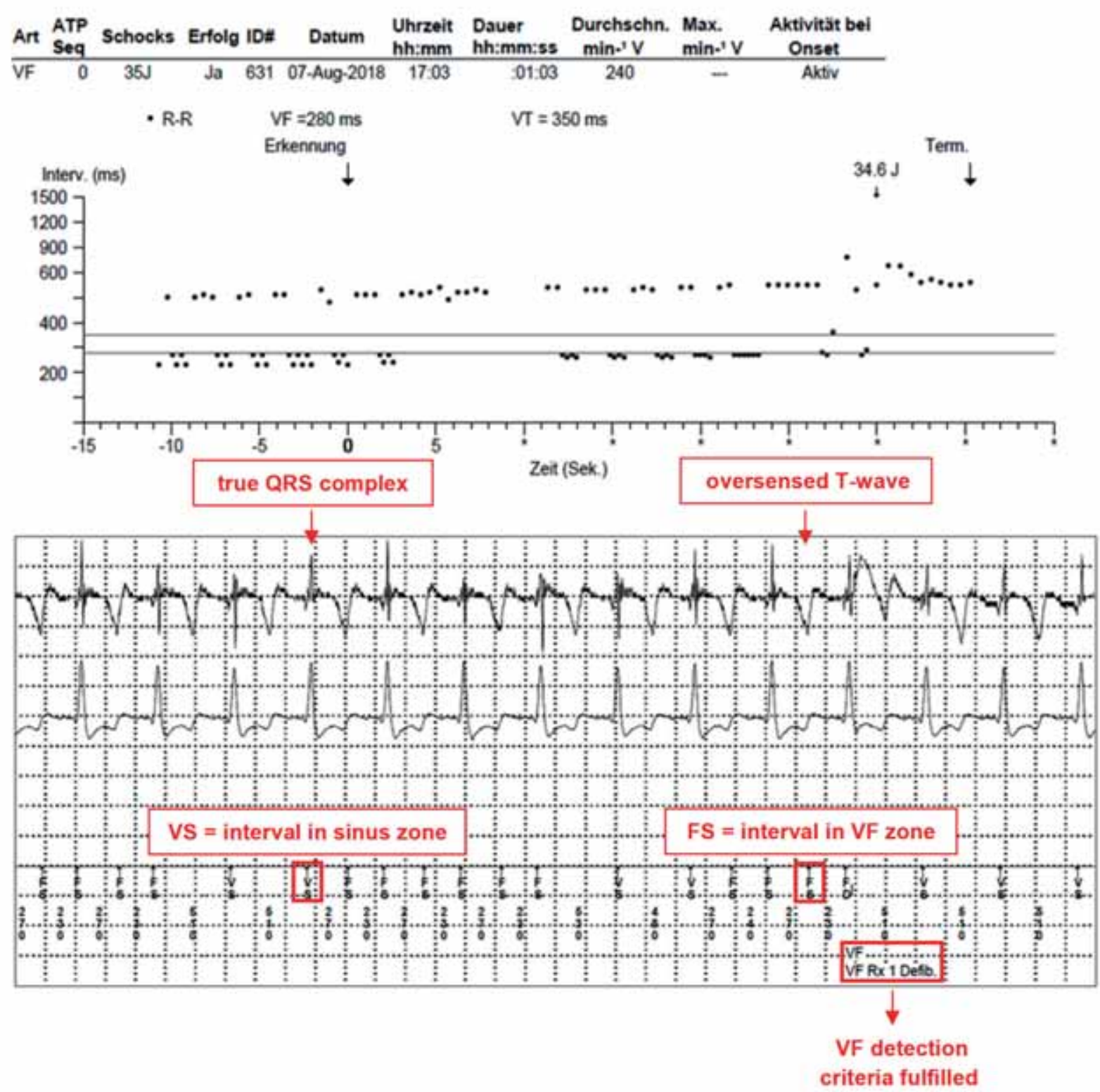

FIGURE 2. Misclassified VF episode due to intermittent T-wave oversensing leading to inappropriate shock delivery 


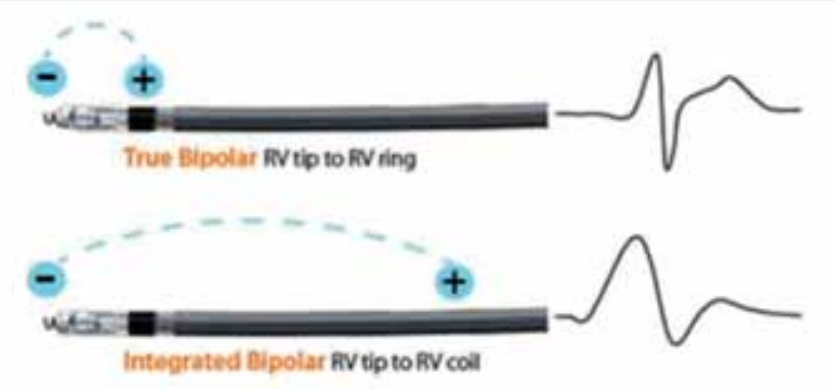

FIGURE 3. Lead configuration of true and integrated bipolar sensing polarities in Medtronic devices (source: https://www.medtronicacademy.com/features/ rv-sense-polarity-feature)

\section{Discussion}

Implantation of an ICD is still the most effective therapeutic option for the prevention of sudden cardiac death (4). However, up to $25 \%$ of ICD patients may experience complications as a result of ventricular oversensing, most commonly related to T-waves (5). To ensure appropriate detection of ventricular fibrillation while avoiding T-wave oversensing, current expert opinion recommends that sinus rhythm R-wave amplitude on the ventricular electrogram should exceed $5.0 \mathrm{mV}$ at implantation. A retrospective analysis of the EMPIRIC $(n=900$ patients) and WAVE ( $n=1122$ patients) clinical trials however suggests, that R-waves $\geq 3 \mathrm{mV}$ could be sufficient (6). Nonetheless, patients with T-wave oversensing refractory to reprogramming often require surgical lead revision $(2,3)$ with all its well-known risks, including system infection (7).

Depending on the manufacturer, ICDs are available with two different right ventricular lead types and sensing configurations, respectively. True bipolar configuration records intracardiac signals between the distal tip and a proximal ring electrode, whereas the electrical vector of an integrated bipolar configuration (also called extended bipolar) occurs between the tip and the more distal coil electrode (Figure 3). In spite of the bigger surface in the integrated bipolar mode, oversensing of external electrical noise or myopotentials can still be avoided.

Which sensing polarity is superior to the other is controversial and probably depends on individual patient-specific factors. Some studies $(8,9)$ revealed no significant difference between true and integrated bipolar sensing polarities regarding R-wave amplitude or detection of ventricular fibrillation. In a multicentre retrospective study of patients with Brugada syndrome, T-wave oversensing was more often reported with true bipolar sensing compared to integrated bipolar programming (10), while Weretka et al. demonstrated a higher incidence of T-wave oversensing with integrated bipolar leads (5). Currently, Medtronic is the only manufacturer offering ICDs with capability of both true and integrated bipolar sensing configurations (available in Maximo II or newer models from 2008).
In our patient we could avoid a surgical lead revision by implanting an ICD capable of switching sensing polarity. By reprogramming the sensing vector, a stable recovery of the R-wave amplitude (from $3.4 \mathrm{mV}$ to $9.8 \mathrm{mV}$ ) was achieved. Although other programming options to handle T-wave oversensing (e.g. T-wave oversensing algorithms) are available not only in Medtronic devices, our findings endorse the development of ICDs with the programming capability to change the sensing vector configuration.

\section{Conclusions}

In patients with low R-wave amplitudes, surgical lead revision could be avoided in some cases by changing the sensing vector. Development of this function is endorsed in all commercially available ICDs.

\section{Declaration of interest}

The authors have reported that they have no relationships relevant to the contents of this paper to disclose. They attest that patient consent was appropriate.

\section{References}

1. Lillo-Castellano JM, Marina-Breysse M, Gómez-Gallanti A, et al. Safety threshold of R-wave amplitudes in patients with implantable cardioverter defibrillator. Heart 2016; 102: 1662-1670. doi: 10.1136/ heartjnl-2016-309295

2. Srivathsan K, Scott LR, Altemose GT. T-wave oversensing and inappropriate shocks: a case report. Europace 2008; 10: 552-555. doi: 10.1093/europace/eun083

3. Porres JM, Brugada J, Marco P, et al. T wave oversensing by a cardioverter defibrillator implanted in a patient with the Brugada syndrome. Pacing Clin Electrophysiol 2004; 27: 1563-1565. doi: 10.1111/j.1540-8159.2004.00677.x

4. Goldenberg I, Huang DT, Nielsen JC. The role of implantable cardioverter-defibrillators and sudden cardiac death prevention: indications, device selection, and outcome. Eur Heart J 2019 Nov 12. pii: ehz788. doi: 10.1093/eurheartj/ehz788

5. Weretka S, Michaelsen J, Becker R, et al. Ventricular oversensing: a study of 101 patients implanted with dual chamber defibrillators and two different lead systems. Pacing Clin Electrophysiol 2003; 26 : 65-70. doi: 10.1046/j.1460-9592.2003.00152.x

6. Ruetz LL, Koehler JL, Brown ML, et al. Sinus rhythm R-wave amplitude as a predictor of ventricular fibrillation undersensing in patients with implantable cardioverter-defibrillator. Heart Rhythm 2015; 12: 2411-8. doi: 10.1016/j.hrthm.2015.08.012

7. Poole JE, Gleva MJ, Mela T, et al. Complication rates associated with pacemaker or implantable cardioverter-defibrillator generator replacements and upgrade procedures: results from the REPLACE registry. Circulation 2010; 122: 1553-61. doi: 10.1161/CIRCULATIONAHA.110.976076

8. Tolat AV, Woiciechowski M, Kahr R, et al. A prospective study comparing the sensed $\mathrm{R}$ wave in bipolar and extended bipolar configurations: the PropR study. Pacing Clin Electrophysiol 2013; 36: 541-6. doi: 10.1111/pace.12093

9. Verga TA, Gillberg JM, Greenberg RM, et al. True bipolar and integrated bipolar sensing and detection by implantable defibrillators. Pacing Clin Electrophysiol 2011 Nov; 3411: 1561-8. doi: 10.1111/j.1540-8159.2011.03182.x

10. Rodríguez-Mañero $M$, de Asmundis $C$, Sacher $F$, et al. T-wave oversensing in patients with Brugada syndrome: true bipolar versus integrated bipolar implantable cardioverter defibrillator leads: multicenter retrospective study. Circ Arrhythm Electrophysiol 2015; 8: 792-8. doi: 10.1161/CIRCEP.115.002871 